\title{
BIOACTIVITY OF AQUEOUS EXTRACTS OF Clibadium sylvestre (AUBL.) BAILL. AND Derris amazonica KILLIP ON THE APHID Myzus persicae (SULZER, 1776) (HEMIPTERA: APHIDIDAE)
}

\author{
Bioatividade de extratos aquosos de Clibadium sylvestre (Aubl.) Baill. e Derris \\ amazonica Killip no controle do pulgão Myzus persicae (Sulzer) (Hemiptera: Aphididae) \\ Camila Cramer Filgueiras ${ }^{1}$, Paulo Roberto Silva Farias², Maria das Graças Cardoso ${ }^{3}$, \\ José Djair Vendramim ${ }^{4}$, Edson Marcos Leal Soares Ramos ${ }^{5}$, Fernando Rodrigo de Oliveira Cantão ${ }^{6}$
}

\begin{abstract}
Studies with botanical insecticides have become more popular as an alternative to Integrated Pest Management. The purpose of this study was to evaluate the effect of leaf and fruit aqueous extracts, from the species Clibadium sylvestre, and leaves and root of Derris amazonica species at concentrations of 0,1,2,4 and 8\%, in the control of the aphid Myzus persicae (Hemiptera: Aphididae). Four experiments were conducted; two tests with choice preference and two tests with no choice preference, giving nine treatments and five repetitions. Phytochemical screening was carried out from the leaves and fruit of the species $C$. sylvestre and leaves and root of D. amazonica. Evaluations of mortality, number of nymphs, and deterrence index of the insects were conducted 24 , 48 and $72 \mathrm{~h}$ after the application of the extracts. The aqueous extracts tested from $C$. sylvestre fruit concentrations had the highest mortality compared to the control; in the analysis of the number of the nymphs, the aqueous extract from fruit at $8 \%$ concentration had a higher efficiency than the other treatments. The $D$. amazonica leaves extract at $1 \%$ concentration showed the highest mortality and the lowest number of nymphs. The D. amazonica root extracts increased mortality at all concentrations tested, and the $8 \%$ concentration had the fewest nymphs. All treatments showed a deterrent effect. The $72 \mathrm{~h}$ period showed the greatest effect of the extracts, on two species of insects.
\end{abstract}

Index terms: Organic agriculture, botanical insecticides, cunaniol, rotenone.

\begin{abstract}
RESUMO
Estudos com inseticidas botânicos vêm ganhando espaço como alternativa no Manejo Integrado de Pragas. Conduziu-se este trabalho com o objetivo de avaliar o efeito de extratos aquosos de folhas e frutos da espécie Clibadium sylvestre, e folhas e raízes da espécie Derris amazonica nas concentrações 0, 1, 2, 4 e 8\%, no controle do pulgão Myzus persicae (Hemiptera: Aphididae). Foram conduzidos quatro ensaios, dois testes de preferência sem chance de escolha e dois testes de preferência com chance de escolha, totalizando nove tratamentos com cinco repetições. Foi realizada a triagem fitoquímica das folhas e dos frutos da espécie $C$. sylvestre e das folhas e das raízes de D. amazonica. As avaliações de mortalidade, número de ninfas e índice de deterrência dos insetos, foram realizadas 24, 48 e 72 horas após a aplicação dos extratos. Os extratos aquosos do fruto do $C$. sylvestre nas concentrações testadas apresentaram maior mortalidade frente à testemunha, na análise do número de ninfas, o extrato aquoso do fruto do $C$. sylvestre a $8 \%$ apresentou maior eficiência que os demais tratamentos. O extrato da folha de D. amazonica na concentração $1 \%$ apresentou maior mortalidade e menor número de ninfas que os demais tratamentos. Os extratos da raiz de $D$. amazonica aumentaram a mortalidade em todas as concentrações testadas e a concentração $8 \%$ da raiz de D. amazonica, apresentou menor número de ninfas. Todos os tratamentos testados apresentaram efeito deterrente. O período de 72 horas foi o que apresentou maior efeito dos extratos, das duas espécies estudadas sobre os insetos.
\end{abstract}

Termos para indexação: Agricultura orgânica, inseticidas botânicos, cunaniol, rotenona.

\section{(Received in march 21, 2011 and approved in june 1, 2011)}

\section{INTRODUCTION}

Modern agricultural success is partially related to the widespread use of synthetic chemical products for plant protection; however, concerns over the potential impacts of pesticides as residues in food and in the environment has grown in recent years (DAYAN et al., 2009). New pesticides, including natural products, are being discovered and developed in order to replace some synthetic compounds used in the past. These are used to

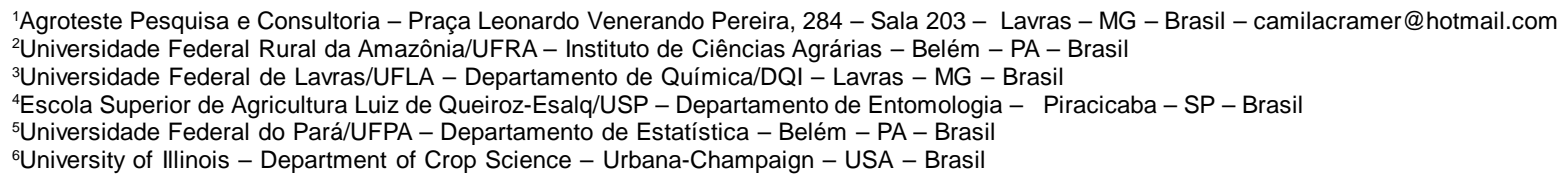


combat the evolution of insect resistance to existing active ingredients (COPPINGER; DUKE, 2007). Among the alternative methods, we can highlight the use of plant extracts as a viable strategy, when associated with other methods of control (CAVALCANTE et al., 2006).

Clibadium sylvestre, is a species belonging to the Asteraceae family, found in the North of Brazil. This species is used in predatory fishing by the population in the Amazon region due to its toxic properties. The cunaniol compound present in the $C$. sylvestre leaves acts as an inhibitor of GABA system, affecting the nervous system (COSTA et al., 2006).

The species Derris amazonica is a climbing vine found in the North of Brazil; it is a Fabaceae - Faboideae that usually has a toxic, creamy liquid in the roots, widely used by indigenous and local people to facilitate fishing. It is known that the roots are rich in rotenone, a rotenoid with a broad spectrum insecticide, controlling both adult and immature insects (COSTA et al., 1986; COSTA et al., 1999; AZEVEDO et al., 2005). Costa et al. (1999), reported before 1946, rotenone had already been used as insecticide, and $D$. amazonica plants have a great ability to be employed by the industry, since there is possibility of extraction, stabilization, and standardization of rotenone.

Myzus persicae (Hemiptera: Aphididae), commonly known as the aphid, is a sucking insect which causes a great deal of damage to farming. Blackman and Eastop (2000) reported this pest as a vector of over 120 diseases. The use of systemic insecticides to control aphids is very common; however, Thomazini et al. (2000), reported that successive applications of insecticides increased the probability of invulnerable pest.. Moreover, Franeschini et al. (2001) reported that applications of synthetic insecticides cause negative effects on soil, climate, vegetation, water, animals including humans, and can cause selection of resistant insect mutants.

The aim of this study was to evaluate the effect of aqueous extracts from the leaves and fruits of $C$. sylvestre, and the leaves and roots of $D$. amazonica to control aphid M. persicae.

\section{MATERIALS AND METHODS}

The identification of plant species Clibadium sylvestre and Derris amazonica was performed in the BotanyHerbarium Laboratory of Emílio Goeldi Museum, in Belém PA, which was used for the storage of the species studied.

The phytochemical selections of the leaves and fruits from $C$. sylvestre and the leaves and roots of $D$. amazonica were performed in July 2009, in the Organic Chemistry Laboratory of the Federal University of Lavras.
The experiments were conducted in the Entomology Laboratory of the Federal Rural University of Amazon (UFRA), Belém, Pará, in the period from August to September 2009. The insects used in the trials were obtained from cultivation in wild cabbage plants kept in a netting nursery. The control of other pests and natural enemies was done by hand. Aphids were collected just before the experiment.

\section{Preparation of plant powders from $C$. sylvestre and $D$. amazonica}

Leaves and fruits from C. sylvestre and leaves and roots from D. amazonica, were collected on the campus of UFRA - Belem, in July 2009. After collection, the material was washed, separated by plant structures, and dried in an oven with forced ventilation at a temperature of $40 \pm 2^{\circ} \mathrm{C}$. It was then crushed in a Willey mill (Tecnal), model TB340 , with the aid of a 40 mesh sieve, to obtain a fine powder. The powders obtained were stored in glass containers, separated by vegetation structure, protected from humidity, light, and extreme temperatures (above $30^{\circ} \mathrm{C}$ ), for a maximum period of 30 days after collection.

\section{Phytochemical screening}

10-gram samples of each plant powder were refluxed with heating in ethanol $70 \%$ for $24 \mathrm{~h}$. Subsequently, the material was filtered in Buchner funnel, concentrated on rotary evaporator, and kept in an oven to remove excess moisture. The phytochemical prospection of different plant structures was developed by qualitative assessments to organic acids, reducing sugars, polysaccharides, proteins and amino acids, tannins, catechins, flavonoids, cardiac glycosides, sesquiterpenelactone and other lactones, azulenes, carotenoids, steroids and triterpenoids, depsides and depsidons, coumarins derivatives, frothy saponins, alkaloids and anthraquinones. They were performed using Matos' methodology (1988).

\section{Collection and application of the extracts}

Aqueous extracts were obtained by mixing the powder in distilled water at the desired concentrations (weight/volume: $\mathrm{g} / \mathrm{mL}$ ), according to each treatment and manually homogenizing the mixtures. After $24 \mathrm{~h}$ of standby time, the solution was filtered to obtain a homogeneous solution without waste. Extracts were used with a maximum of $48 \mathrm{~h}$ of rest.

\section{Treatments}

In preference tests, with and without choice, sections of the wild cabbage leaves were treated with 
extracts, by dipping them in the solutions according to the treatment. The treatments were: $C$. sylvestre leaves (CL), $C$. sylvestre fruit (CF), D. amazonica leaves (TL) and $D$. amazonica root (TR) at concentrations of $0 \%$ (control), $1 \%, 2 \%, 4 \%$ and $8 \%$ (grams of plant powder diluted in $100 \mathrm{ml}$ of water).

\section{No choice preference test}

The treated sections of wild cabbage leaves were placed (one leaf per dish) in the centre of a petri dish $(4 \mathrm{~cm}$ diameter) containing an agar layer concentration of $0.6 \%$. 10 adult aphids/dish were placed on the leaves, after which the dishes were wrapped in plastic film, to prevent the insects from escaping, and kept in a temperature-controlled room (RH $70 \pm 5 \%$, temperature $25 \pm 2^{\circ} \mathrm{C}$ and photoperiod of $12 \mathrm{~h}$ ) throughout the entire test application period. After 24, 48 and $72 \mathrm{~h}$, mortality and number of nymphs were evaluated.

\section{Preference test with choice}

In Petri dishes ( $8 \mathrm{~cm}$ in diameter) containing an agar layer concentration $0.6 \%$, sections of wild cabbage leaves, which were treated with the extracts and water (control), were placed in an equidistant format. In the center of each dish, 10 adult aphids were released, after which the dishes were wrapped in plastic film and kept in a temperaturecontrolled room ( $\mathrm{RH} 70 \pm 5 \%$, temperature $25 \pm 2^{\circ} \mathrm{C}$ and photoperiod of $12 \mathrm{~h}$ ), throughout the entire test application period. Evaluations were performed 24, 48 and $72 \mathrm{~h}$ after the commencement of the test, which evaluated the number of nymphs in each treatment for determination of Index Deterrence. The Index Deterrence was calculated by the formula: $\mathrm{ID}=[(\mathrm{IC}-\mathrm{IT}) /(\mathrm{IC}+\mathrm{IT})] * 100$, adapted from ObengOfori (1995), where ID is the index of deterrence, IC number of nymphs on the plant control (water) and IT in the number of nymphs treated with plant extract. The classification used was: ID $>0$ deterrent extract, ID $<0$ neutral extract.

\section{Statistical analysis}

The experimental design was completely randomized, with nine treatments and four repetitions. The data was transformed into root $(x+0.5)$, and analyzed by repeated measures in time for the no choice preference test. The data was submitted to analysis of variance and compared using the Tukey test at $5 \%$ and $1 \%$ of probability, using the program SAS (1999).

\section{RESULTS AND DISCUSSION}

Phytochemical prospection on leaves and fruit from C. sylvestre and leaves and roots from $D$. amazonica are shown in Table 1. The secondary chemical substances are related to the plant's defense, and some of these compounds have been already tested, and showed profound effects on feeding behavior, oviposition, and growth of phytophagous insects (HARBONE, 1994; CHEN, 2008). Mello; Silva-Filho (2002) also reported that the

Table 1 - Phytochemical prospection on leaves and fruit from Clibadium sylvestre and leaves and root from Derris amazonica.

\begin{tabular}{|c|c|c|c|c|}
\hline \multirow{2}{*}{ Chemical Compounds } & \multicolumn{2}{|c|}{ C. sylvestre } & \multicolumn{2}{|c|}{ D. amazonica } \\
\hline & Leaves & Fruit & Leaves & Root \\
\hline Reducing sugar & - & + & + & + \\
\hline Proteins and amino acids & - & + & + & + \\
\hline Tannins & + & + & + & - \\
\hline Flavonoids & - & - & + & + \\
\hline Cardiac glycosides & + & - & - & - \\
\hline Sesquiterpenelactone and other lactones & + & + & + & + \\
\hline Azulenes & + & + & + & - \\
\hline Carotenoids & + & + & + & - \\
\hline Steroids and triterpenoids & + & + & + & - \\
\hline Depsides and depsidons & + & + & + & + \\
\hline Derivatives of coumarins & - & + & + & + \\
\hline Frothy saponins & - & - & + & + \\
\hline Alkaloids & - & + & - & - \\
\hline
\end{tabular}

Note: (-) no reaction; (+) positive reaction. 
secondary compounds of plants are involved in protecting the plant against herbivory. Nottingham and Hardie (2008) observed that several species of aphids, including $M$. persicae, are influenced by volatile compounds present in plants.

The presence of secondary compounds such as tannins, glycosides, sesquiterpenes, carotenoids, terpenoids and alkaloids, are evidences of efficacy of the plant under study in insect control, since the compounds reported show an adverse effect on insects (CAVALCANTI et al., 2005; SCHOONHOVEN et al., 2005). Lara (1991) reports that the sterols may disturb the insects by blocking their transformation process from larvae to adult, and killing them at some point during metamorphosis. Schoonhoven et al. (2005) reported that saponins influence the growth and development of insects and flavonoids are considered toxic or feeding deterrents for insects. As an example, rotenone, nicotine and pyrethrins, are substances used extensively as insecticides. The alkaloids act as feeding and/or toxic deterrents for several kinds of insects (SCHOONHOVEN et al., 2005). Different secondary compounds present in different structures of the studied plants were observed. Srivastava et al. (2008) also emphasized that variation in the secondary metabolites depended on the plant structure, giving a positive relation with the biological activity exerted by the plant.

For the aqueous extracts of $C$. sylvestre leaves at the concentrations tested (Table 2), the mortality evaluation of adult insects and the evaluation number of nymphs observed no significant difference between the treatments compared to the control. Regarding the insects' exposure time to the extracts, there were differences in the mortality evaluation period and the number of nymphs. Results showed that there were higher mortality and number of nymphs on the third day (72 h) and lower mortality and number of nymphs on the first day $(24 \mathrm{~h})$. In the first evaluation (24h), no effect between the treatments CF1\%, $\mathrm{CF} 2 \%$ and $\mathrm{CF} 4 \%$ and favorable results to the control and to CF8\% treatment was observed, this fact can be justified as a case of hormesis extract. In the second and third evaluation, the extracts of the fruit of $C$. sylvestre showed no differences among the concentrations tested, and they all showed mortality above the control. This indicates their efficiency in the question of insect mortality. Only the treatment at $8 \%$ of concentration differed from the control. Treatments at $1 \%$ and $2 \%$ showed a lower number of nymphs. In relation to the different times of evaluation, the third evaluation (72h) showed the highest mortality values and number of nymphs, which can be attributed to the longer exposure time of the insects to the extracts. The

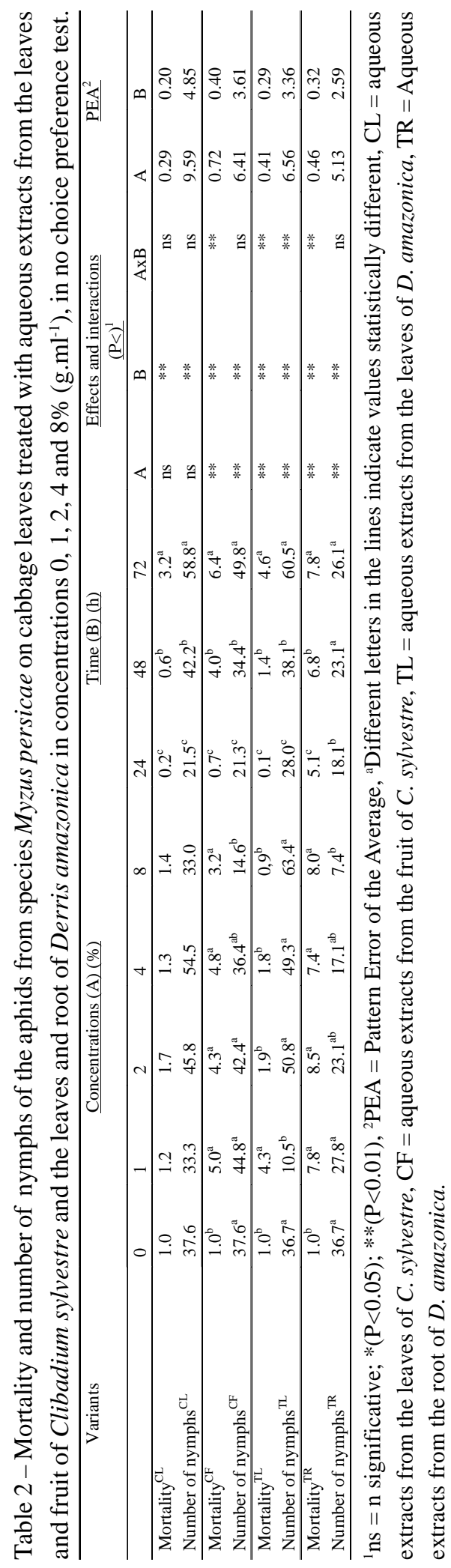


fact that the largest number of nymphs coincided with the highest mortality value, during $72 \mathrm{~h}$, can be attributed to defense tactics of the insects. This is because, when they feel threatened, they tend to increase the number of descendants, avoiding extinction. There are only a few studies on the plant species $C$. sylvestre on insect control; however, the numbers of researchers is increasing, with new studies looking for new plant species as potential botanical insecticides. Bogorni; Vendramim (2005) found the efficiency of the extract of Trichilia pallens in reducing the survival of $S$. frugiperda.

In the mortality analysis of adult insects with aqueous extracts of the leaves of D. amazonica at 0, 1, 2, 4 and $8 \%$ concentrations (Table 2 ), the following was observed: the first evaluation $(24 \mathrm{~h})$ no effect of the extracts at any of the tested concentrations compared to the control was found; in the second evaluation (48h), only the TL1\% treatment had a higher mortality when compared to the control; in the third evaluation (72h), the TL1\%, TL2\% and TL4\% treatments were not different from the control, however, the TL8\% treatment had lower mortality than other treatments and the control. The effect of the extracts after $48 \mathrm{~h}$ may have occurred, due to the need for more time for the botanical insecticides to act. In relation to the time (Table 2), the third evaluation (72h) was the period with the greatest mortality of insects. This may be explained by the longer period of exposure of the insects to the extracts. In the analysis on the number of nymphs (Table 2) present on the cabbage leaves treated with leaf extracts of $D$. amazonica, the first evaluation (24h) showed no effect of extracts on the pest in any treatment.

In the second and third evaluations ( $48 \mathrm{~h}$ and $72 \mathrm{~h}$ ), only the TL $1 \%$ treatment differed from the control, showing a lower number of nymphs. In mortality evaluations and the number of nymphs evaluations, the $1 \%$ dosage, presented significant results against the higher doses tested. This can be justified as a case of hormesis, where a product has the opposite effect at high doses to low doses. In the mortality evaluation of adults on cabbage plants treated with aqueous extracts from the root of $D$. amazonica (Table 2), the concentrations tested 1, 2, 4, and $8 \%$ had higher mortality of adult insects, compared to the control, in the three periods evaluated. In relation to the time, only the control presented variation during the mortality evaluation time of $M$. persicae. The other treatments showed no significant difference between the evaluation days, indicating the same effect of the extracts in the three days of evaluation. In relation to the different periods evaluated, a greater number of nymphs in the second (48h) and third (72h) evaluations were observed.
The best effect of extracts from the root of $D$. amazonica, when compared with the effect of the leaf extracts, can be explained by the higher concentration of rotenone in the root compared to the leaves. According to Fukami et al. (1971), rotenone is the main representative of rotenoids, and it is extracted from the roots and stems of species Lonchocarpus, Tephrosia or Derris. Cabras et al. (2002) performed a field experiment to evaluate the rotenone persistence on olives. The results showed the residues decreased from the fourth day, but they found residues of rotenone after ten days of spraying. According to Veitch (2007), rotenoids are important subclasses of isoflavones due to their insecticidal properties. Rotenoids have broadspectrum insecticides that target groups including coleoptera and hemiptera (MAINI; MORALO, 1993; AZEVEDO et al., 2005). The different effect between the structures of the same plant in insects may be related to the presence of secondary compounds in each structure and the amount present. It is already known that plants show variation in secondary metabolite production according to the part studied (SILVA et al., 2002). According to Srivastava et al. (2008), the variation in content of secondary metabolites depending on the analyzed plant structure presents a positive correlation with biological activity.

The presence of secondary compounds such as tannins, glycosides, sesquiterpenes, carotenoids, terpenoids and alkaloids, are evidence of efficacy of the plant under study in insect control, since the compounds reported show an adverse effect on insects (CAVALCANTI et al., 2005 SCHOONHOVEN et al., 2005).

The aqueous extracts from leaves and fruits of $C$. sylvestre showed deterrent effects (Table 3 ) in the test with choice. The deterrence values from the leaf extracts of $C$. sylvestre presented $82 \%$ average deterrence in the first evaluation $(24 \mathrm{~h})$, in the second evaluation ( $48 \mathrm{~h}) 56 \%$, and in the third evaluation $(72 \mathrm{~h}$ ) an average of $16 \%$. According to the deterrence percentage values of the extracts from the fruit of $C$. Sylvestre, the first evaluation had an average of $77 \%$, the second an average of $41 \%$ and the third evaluation an average of $15 \%$.

The leaf extracts from D. amazonica, in all concentrations, showed deterrent effects according to the number of nymphs (Table 3 ) in the preference test with choice, with averages in the first evaluation of $50 \%$, in the second and third close to $25 \%$. The extracts from the root of $D$. amazonica, observed deterrent effects only in the first two evaluations ( 24 and $48 \mathrm{~h}$ ), in the third evaluation there was a neutral effect of the extracts in all concentrations tested. 
Table 3 - Deterrence rate to the number of nymphs of Myzus persicae in sections of cabbage leaf sections treated with aqueous extracts from the leaves and fruit of Clibadium sylvestres and leaves and roots of Derris amazonica.

\begin{tabular}{lcccccc}
\hline Treatments & $24 \mathrm{~h}$ & Effect & $48 \mathrm{~h}$ & Effect & $72 \mathrm{~h}$ & Effect \\
\hline CL 1\% & 63 & $\mathrm{D}$ & 60 & $\mathrm{D}$ & 4 & $\mathrm{D}$ \\
CL 2\% & 100 & $\mathrm{D}$ & 39 & $\mathrm{D}$ & 25 & $\mathrm{D}$ \\
CL 4\% & 86 & $\mathrm{D}$ & 76 & $\mathrm{D}$ & 11 & $\mathrm{D}$ \\
CL 8\% & 80 & $\mathrm{D}$ & 50 & $\mathrm{D}$ & 26 & $\mathrm{D}$ \\
\hline CF 1\% & 41 & $\mathrm{D}$ & 21 & $\mathrm{D}$ & 5 & $\mathrm{D}$ \\
CF 2\% & 83 & $\mathrm{D}$ & 69 & $\mathrm{D}$ & 8 & $\mathrm{D}$ \\
CF 4\% & 93 & $\mathrm{D}$ & 48 & $\mathrm{D}$ & 33 & $\mathrm{D}$ \\
CF 8\% & 94 & $\mathrm{D}$ & 29 & $\mathrm{D}$ & 16 & $\mathrm{D}$ \\
\hline TL 1\% & 57 & $\mathrm{D}$ & 20 & $\mathrm{D}$ & 45 & $\mathrm{D}$ \\
TL 2\% & 35 & $\mathrm{D}$ & 13 & $\mathrm{D}$ & 20 & $\mathrm{D}$ \\
TL 4\% & 62 & $\mathrm{D}$ & 38 & $\mathrm{D}$ & 19 & $\mathrm{D}$ \\
TL 8\% & 64 & $\mathrm{D}$ & 22 & $\mathrm{D}$ & 16 & $\mathrm{D}$ \\
\hline TR 1\% & 88 & $\mathrm{D}$ & 7 & $\mathrm{D}$ & -11 & $\mathrm{~N}$ \\
TR 2\% & 66 & $\mathrm{D}$ & 24 & $\mathrm{D}$ & -25 & $\mathrm{~N}$ \\
TR 4\% & 71 & $\mathrm{D}$ & 21 & $\mathrm{D}$ & -10 & $\mathrm{~N}$ \\
TR 8\% & 50 & $\mathrm{D}$ & 33 & $\mathrm{D}$ & -14 & $\mathrm{~N}$ \\
\hline
\end{tabular}

$\mathrm{D}=$ deterrent, $\mathrm{N}=$ neutral, $\mathrm{CL}=$ aqueous extracts from the leaves of $C$. sylvestre, $\mathrm{CF}=$ aqueous extracts from the fruit of $C$. sylvestre, $\mathrm{TL}=$ aqueous extracts from the leaves of $D$. amazonica, $\mathrm{TR}=$ Aqueous extracts from the root of $D$. amazonica.

The deterrent effect observed in almost all treatments can be explained by the presence of some secondary compounds with insecticide action, such as flavonoids, tannins, alkaloids, and terpenoids. Cavalcante et al. (2006) noticed that the plant species that cause the highest mortality rates in young forms of Bemisia tabaci, were those with the highest concentrations of tannins. The terpenoids present good solubility and high toxic action. The alkaloids act as feeding deterrents and/or toxic to many insect species (SCHOONHOVEN et al., 2005).

Medeiros et al. (2005), studying the effect of aqueous extracts on the pest Plutella xylostella, reported a deterrent effect by the majority of the extracts on oviposition of this insect, also emphasizing that the extracts of Enterolobium contortisilliquum, from Sapindus saponaria and Trichilia pallida, result in 100\% deterrence. Lima et al., (2008) reported the repellent effect and/or deterrent on aphids, studying different concentrations of essential oils from Illicium verum and Cymbopogon citratus. Bogorni and Vendramim (2005), observed extracts of different structures from the genus Trichilia affect the development of S. frugiperda. Azadirachtin, a terpenoid found in leaves and fruits of Azadirachta indica, is considered one of the strongest deterrents currently known in the literature (MEDINA et al., 2004). Oliveira et al. (2007) reported the efficiency of plant extracts in controlling S. frugiperda.

A reduction is observed in the rate of deterrence during the evaluations. This fact can be explained by rapid degradability and low residual power of plant extracts (SCHOONHOVEN et al., 2005). According to this author, the rotenone, a flavonoid which is present in a large quantity in the roots of D. amazonica, is a compound used as insecticide due to its toxicity and mainly for degrading quickly. It also does not accumulate along the food chain.

\section{CONCLUSION}

Extracts from the fruit of $C$. sylvestre in all concentrations affected the mortality of the $M$. persicae, and at concentration of $8 \%$ reduced the number of nymphs. The extracts from the leaves and fruit of $C$. sylvestre in all concentrations showed deterrent effects. Leaf extracts of D. amazonica at concentrations of $1 \%$ increased the mortality and decreased the number of nymphs. The root extracts of D. amazonica in all concentrations influenced the mortality and at a concentration of $8 \%$ reduced the number of nymphs. The extracts from leaves and fruit of $D$. amazonica in all concentrations showed the deterrent effect. The evaluated time with the greatest effect of the 
extracts from both species of Myzus, was the third evaluation $(72 \mathrm{~h})$.

\section{ACKNOWLEDGMENTS}

The authors wish to thank DAAD (Deutscher Akademischer Austausch Dienst) for financing the fellowship.

\section{REFERENCES}

AZEVEDO, F.R. et al. Eficiência de produtos naturais para o controle de Bemisia tabaci biótipo B (Hemiptera: Aleyrodidae) em meloeiro. Arquivos do Instituto Biológico. v. 72, p. 73-79, 2005.

BLACKMAN, R.L.; EASTOP, V.P. Aphids on the world's crops: an identification guide. Chichester: Wiley, 2000, $476 \mathrm{p}$.

BOGORNI, P.C, VENDRAMIM, J.D. Efeito subletal de extratos aquosos de Trichilia spp. sobre o desenvolvimento de Spodoptera frugiperda em milho. Neotropical Entomology. v. 34, p. 311-31, 2005.

CABRAS, P. et al. Rotenone residues on olives and in olive oil. Journal of Agricultural and Food Chemistry. v. 50p. 2576-2580, 2002.

CAVALCANTE, GM.; MOREIRA, A.F.C.; VASCONCELOS, S.D. Potencialidade inseticida de extratos aquosos de essências florestais sobre a moscabranca. Pesquisa Agropecuária Brasileira. Brasília ,v. 41, p. 9-14, 2006.

CAVALCANTI, L.S.; et al. Indução de resistência em plantas a patógenos e insetos. Piracicaba: FEALQ, 2005, $263 p$.

CHEN, M.S. Inducible direct plant defense against insect herbivores: a review. Insect Science. v. 15, p. 101-114, 2008 .

COPPING, L.G.; DUKE, S.O. Natural products that have been used commercially as crop protection agents. Pest Management Science. v. 63, p. 524- 554, 2007.

COSTAE. A. et al. Behavioral effect of a neurotoxic compound isolated from Clibadium surinamenses L. (Asteraceae). Neurotoxicology and Teratoloy. v. 28, p. 349-353, 2006.
COSTA, N.A. et al. Uso do Timbó-urucu no controle do piolho (Haemotopinus tuberculatus) em bubalinos.

Belém: Embrapa Amazônia Oriental, 1986, 16p.

COSTA, J.P.C.; ALVES, S.M.; BELO, M. Diferença entre as espécies de timbó (Derris spp. Fabaceae) de diferentes regiões da Amazônia no controle da Musca domestica L. Acta Amazônica. v. 29: p. 573-583, 1999.

DAYAN, F.E.; CANTRELL, C.L.; DUKE, S.O. Natural products in crop protection. Bioorganic e Medicinal Chemistry. v. 17 p. 4022-4034, 2009

FRANCESCHINI, M. et al. Biotecnologia aplicada ao controle biológico. Biotecnologia Ciência e

Desenvolvimento. v. 23, p. 32-37, 2001.

FUKAMI, H.; NAKAJIMA, M. In: JACOBSON, M.; CROSBY, D.G. Naturally Occurring Insecticides. New York: Marcel Dekker, 1971, 71p.

HARBONE, J.B. Introduction to ecological biochemistry. London: Academic, 1994, 384p.

LARA, F.M. Princípios de resistência de plantas a insetos. São Paulo: Ícone, 1991, 336p.

LIMA, R.K. et al. Composição dos óleos essenciais de Anis-estrelado (Illicium verum L.) e de Capim-limão [Cymbopogon citratus] (DC.) Stapf: Avaliação do efeito repelente sobre Brevicoryne brassicae (L.) (Hemiptera: Aphididae). Bioassay 3: on line. 2008.

MAINI, P.N.; MORALO, B. Molluscicidal Activity of Derris elliptica (Leguminosae). Journal of Science. v. 122, p. 61-75, 1993.

MATOS, F.J.A. Introduçãoa Fitoquímica Experimental. Fortaleza: Editora UFC, 1998, 128p.

MEDEIROS, C.A.M. et al. Efeito de extratos aquosos de plantas na oviposição da traça-das-crucíferas, em couve. Bragantia. Campinas, v. 64, p. 227-232, 2005.

MEDINA, P. et al. Influence of azadirachtin, a botanical insecticide, on Chrysoperla carnea (Stephens) reproduction: toxicity and ultrastructural approach. Journal of Economic Entomology. v. 97, p. 43-50, 2004. 
MELLO, M.O; SILVA-FILHO, M.C. Plant-insect interactions: an evolutionary arms race between two distinct defense mechanisms. Brazilian Journal of Plant Physiology. v. 14, p. 71-81, 2002.

NOTTINGHAM, S.F.; HARDIE, J. Flight behavior of the black bean aphid, Aphis fabae, and the cabbage aphid, Brevicoryne brassicae, in host and non-host plant odour. Physiology Entomology. v. 18, p. 389-394, 2008.

OBENG-OFORI, D. Plant oils as grain protectants against infestations of Cryptolestes pusillus and Rhyzopertha dominica in stored grain. Entomologia Experimentalis et Applicata. v. 77, p. 133-139, 1995.

OLIVEIRA, M.S.S. et al. Eficiência de produtos vegetais no controle da lagarta-do-cartucho-do-milho Spodoptera frugiperda (J.E.SMITH,1797) (Lepidoptera:Noctuidae). Ciência e Agrotecnologia. Lavras, v. 2, p. 326-331, 2007.
SCHOONHOVEN, L.M.; LOON, J.J.A.; DICKE, M. Insect-plant biology. New York: Oxford, 2005, 421p.

SILVA, B.M. et al. Phenolic profile of quince fruit (Cydonia oblonga Miller) (Pulp and Peel). Journal of Agricultural and Food Chemistry. v. 50, p. 4615-4618, 2002.

SRIVASTAVA, A. et al. Larvicidal activity of an indigenous plant, Centratherum anthelminticum. Journal of Environmental Biology. v. 29 p. 669-672, 2008.

THOMAZINI, A.P.B.W.; Vendramim, J.D.; Lopes, M.T.R. Extratos aquosos de Trichilia pallida e a traça-dotomateiro. Scientia Agricola. Piracicaba, v.57, p.13-17, 2000 .

VEITCH, N. C. Isoflavonoids of the Leguminosae. Natural Products Reports. v.24, p.416-464, 2007. 